\title{
WILLIAM FORD ROBERTSON (1867-1923): HIS STUDY OF NEUROGLIA
}

by

\section{R. R. STURROCK*}

THE PRESENCE of a supporting tissue within the central nervous system was first demonstrated by Keuffel in 1811, ${ }^{1}$ when he showed a definite meshwork left in crosssections of spinal cord after the nervous tissue had been brushed out. He interpreted this as representing prolongations of the pia mater. Arnold in $1845^{2}$ and Virchow in the following year both described a granular ground substance which Virchow was later" to term the neuroglia, literally "nerve-glue". In 1865 Deiters ${ }^{5}$ recognized the cellular nature of the neuroglia, but it was not until the use of Golgi's chrome silver method $^{6}$ became widespread that the cellular independence of the neuroglia came to be recognized. Unfortunately the introduction of Weigert's staining technique ${ }^{7}$ led to a new concept, namely that the neuroglia consisted of a syncytium with extracellular fibres. Weigert's views received support from the work of Reinke, ${ }^{8}$ Eurich, ${ }^{9}$ Whitwell, ${ }^{10}$ Held $^{11}$ and Hardesty, ${ }^{12}$ and was not finally disproved until the advent of electron microscopy. ${ }^{13}$

Towards the end of the nineteenth century most studies on neuroglia centred on the controversy over whether the neuroglia was composed of independent cells and their expansions, or whether it was a syncytium with extracellular fibres. The possibility that there was more than one type of neuroglial cell had been noted by Lewis, ${ }^{14}$ but the lack of suitable staining methods prevented any further progress in this direction until 1899 when William Ford Robertson reported as follows:

... In preparations from the brain of a healthy dog I have found throughout the cortex and in the white matter, numerous small branching cells of a very characteristic aspect. Many of them are uniformly black, but in those in which the black reaction is less marked there can be recognised a rounded nucleus, the diameter of which is about twice that of a red blood corpuscle .... Theprotoplasm is generally small in amount and has a granular aspect. Extending from the protoplasm there are generally from three to six delicate processes which begin to branch at a short distance from the cell, often in a distinctly dichotomous fashion .... They are never very long, seldom extending from the cell body further than to a distance equal to about ten times its diameter. They are not attached to the vessels and indeed appear to have no special relation either to them or to any other tissue element ....

... These facts incline me to the view that it is very probable that in these peculiar and unbranched cells we have a special tissue-element belonging to the nervous system which has not hitherto been distinguished as such. ${ }^{15}$

Thus he was the first to describe the appearance of Cajal's "third element of the nervous system". ${ }^{16}$ Today Robertson's work has been largely forgotten, or neglected, but it seems appropriate now that seventy-five years have elapsed since the publication of his textbook, ${ }^{17}$ that his contribution to neurohistology should be recognized.

*R. R. Sturrock, M.B., Ch.B., Department of Anatomy, The University, Dundee, Scotland. 


\section{William Ford Robertson (1867-1923)}

Robertson was born on 28 July 1867, at the Berwickshire farm of Nottylees, on the south bank of the Tweed, just within the Scottish border. His father died when Robertson was three and after spending the first few years of his education at Eskbank Academy near Dalkeith in Midlothian, he moved to Edinburgh where he completed his studies at George Watson's College. After leaving school he spent two years learning business methods in a lawyer's office. This training probably stood him in good stead in later life when he was deeply involved in administration. He found business not to his liking, however, and entered Edinburgh University as a medical student.

As a student he developed an interest in pathology and spent much of his spare time working in the Pathology Department of Edinburgh Royal Infirmary. During this period he published a paper describing new methods of tissue embedding. ${ }^{18}$

Robertson was graduated MB., C.M., in 1891, and began his postgraduate career in a conventional manner, first as a house physician at Edinburgh Royal Infirmary, and later as a house physician at the Royal Hospital for Sick Children in Edinburgh.

Already his talents as a medical scientist had been recognized, and Sir Thomas Clouston secured his appointment as pathologist to the Royal Edinburgh Asylum in 1893, in place of Dr. James Middlemass, who had been promoted to assistant physician. In 1894, Robertson, in conjunction with Middlemass, began a series of articles on the pathology of the nervous system in relation to mental diseases, in the Edinburgh Medical Journal. ${ }^{10}$ These articles lapsed in 1896, but were later revised, expanded and published as a textbook in $1900 .{ }^{20}$

In 1895 Robertson was awarded the degree of M.D. by Edinburgh University for a thesis entitled "Researches upon the pathology of subdural membrane formation" and in the following year Sir Thomas Clouston prevailed upon the superintendants of the Scottish Asylums, with financial assistance from the Carnegie Trust and Medical Research Council, to set up a Conjoint Laboratory for the Scottish Asylums. The post of pathologist to this laboratory was given to Robertson, and, in fact, the post had been created as a means by which Robertson's services could be permanently retained.

\section{II}

It was around this time that Robertson's interest in neuroglia seems to have been first aroused, but in addition to his personal research work his duties were onerous. He was responsible for organizing courses in special pathological methods for medical staff from the Scottish Asylums, and for visiting asylum laboratories to advise on methods and equipment. He also prepared standard histological material and provided a reference and circulating library of neurological and psychiatric literature.

Nevertheless he found time to carry out research on neuroglia and in 1897 he published two papers, in the first ${ }^{21}$ of which he refuted Weigert's theory that neuroglia consisted of cells and separate fibres, and in the second ${ }^{22}$ he described the 


\section{R. R. Sturrock}

normal and pathological appearances of neuroglia. The most interesting part of the latter paper dealt with the possibility that neuroglia underwent replacement throughout life.

... In the brain of the fully-grown healthy sheep there is strong evidence that a small percentage of the neuroglia cells are proliferating. It may be regarded, I think, as certain that the neuroglia cells only live for a limited number of years, and that therefore a slow process of regeneration must be continually going on. This being so, there must be a cycle in the life-history of a neuroglia-cell, and it is conceivable that cells of different sizes represent different stages in this cycle. ${ }^{23}$

This theory of neuroglial turnover remained unconfirmed until the results of radioautographic studies by Messier, Leblond and Smart in $1958^{24}$ and Smart and Leblond in 1961. ${ }^{25}$ The significance of different sized neuroglial cells in the turnover of neuroglia has been shown in a recent series of papers. ${ }^{26}$

Robertson also produced a similar paper with illustrations, on the normal and pathological histology of neuroglia in $1898,{ }^{27}$ but his most significant contribution to the study of neuroglia was his description in 1899 of a third class of cells in the nervous system in a paper, quoted above. ${ }^{28}$ Robertson had noted the apparent reducing effect of ten per cent formaldehyde on various metals. He carried out a series of experiments using platinum, palladium and silver, and it was during his experiments with platinous oxide that he noted the selective staining of certain elements of the nervous system. These cells differed from the neuroglia cells which were commonly recognized at this time. He was later ${ }^{29}$ to refer to these cells as "mesoglia". He based his belief in the mesodermal origin of these cells on their staining properties.

The cells stained by Robertson's platinum method were probably oligodendrocytes and microglia. Both these types of cells tend to be stained together by certain other metallic stains. Penfield, ${ }^{30}$ who had the opportunity to examine some of Robertson's actual material, was convinced that these cells were oligodendrocytes, but Robertson's description of changes in his mesoglia cells following injury ${ }^{31}$ suggests that in this instance at least, some of the cells were microglia. "The two morbid changes that I have definitely been able to trace in these elements are their development into the well-known granular corpuscles in association with local destructive processes in the nervous tissue ..... In the first of these changes the mesoglia cells exhibit their phagocytic functions."

The debate over the origin of microglia remains the subject of controversy. Mori and Leblond;32 Baron and Gallego;33 Matthews;34 and Sturrock ${ }^{35}$ favour the view of del Rio Hortega ${ }^{36}$ that these cells are mesodermal in origin, while Vaughn and Peters; $;^{87}$ Vaughn and Skoff ${ }^{38}$ and Ling ${ }^{39}$ believe them to be ectodermal derivatives. Although most authors believe oligodendrocytes are ectodermal derivatives, at least one popular student textbook suggests that they, too, may be mesodermal in origin. ${ }^{40}$

Robertson's discovery of the third element of the nervous system went largely unnoticed, possibly because of its lack of acceptance by Ramon y Cajal. He admitted 


\section{William Ford Robertson (1867-1923)}

that he had never read the original communication but knew it only at second hand through a paper by Cerletti.41 Furthermore, Cajal seems to have been reluctant to accept the existence of this third element, because when del Rio Hortega ${ }^{42}$ published his work on the subject at the urging of colleagues, and against the wishes of Cajal, the latter immediately demanded his resignation!

After 1900 Robertson's interests moved on to bacteriology and the place of bacterial infections in mental disease. Unfortunately the results of his researches into neuroglia using silver stains remained unpublished. He died in 1923 at the age of fifty-six, and his services to science were recognized by the award of a Civil List Pension of $£ 100$ to his widow in the following year.

His final work, Walks from Wooler (a small town in Northumberland), ${ }^{43}$ published in 1926, three years after his death, lists in detail the plants and animals found in the Cheviots, and describes many walks in and around these hills. The book contains numerous historical anecdotes and finishes with a brief description of the battle of Flodden. It is written with humour and an affection for the Border country derived from his forebears.

Today his discoveries have largely been forgotten and the credit for the discovery of oligodendroglia and microglia is usually given to del Rio Hortega. Although he was the first to differentiate between the two glial types, there can be no doubt that the first description of the cells of this third element of the nervous system was that of Robertson in $1899 .{ }^{44}$

While the great contribution of del Rio Hortega to neurohistology must be recognized it is appropriate to finish with the words, written the year after Robertson's death, by Wilder Penfield.45 "To Robertson, therefore, belongs the credit of the first description, incomplete though it was, of the protoplasmic expansions of oligodendroglia."

\section{REFERENCES}

1. Keuffel, 'Ueber das Rückenmark', Reil. Archiv., 1811, 10: 124-134.

2. P. F. Arnold, Handbuch der Anatomie des Menschen, Freiburg, iB., 1845, pp. 273-277.

3. R. L. C. Virchow, 'Ueber das granulirte Ansehen der Wandungen der Gehirnventrikel', Allgem. Z. Psychiat., 1846, 3: 242-250.

4. R. L. C. Virchow, Cellular pathology, trans. from the 2 nd ed. by F. Chance, London, Churchill, 1860, pp. 310-318, see p. 315.

5. O. Deiters, Untersuchungen über Gehirn und Rückenmark des Menschen und der Säugetheire, Braunschweig, Vieweg, 1865, pp. $27-52$.

6. C. Golgi, 'Sur l'anatomie microscopique des organes centraux du systeme nerveux', Archs. ital. Biol., 1886, 7: 15-47.

7. C. Weigert, 'Bemerkungen über das Neurogliagerüst des menslichen Centralnervensystems', Anat. Anz., 1890, 5: 543-551.

8. Fr. Reinke, 'Ueber die Neuroglia in der weissen Substanz des Rückenmarks vom erwachsenen Menschen', Arch. mikr. Anat., 1897, 50: 1-14.

9. F. W. Eurich, 'Studies on neuroglia I', Brain, 1897, 20: 114-124; F. W. Eurich, 'Studies on neuroglia II', ibid., 468-487; F. W. Eurich, 'Contributions to the comparative anatomy of the neuroglia', J. Anat. Physiol., Lond., 1898, 32: 688-708.

10. J. R. Whitwell, 'On the structure of the neuroglia', Br. med. J., 1898, i: 681-683.

11. H. Held, 'Über den Bau der Neuroglia und über die Ward der Lymphgafässe in Haut und Schleimhaut', Abh. sachs. Akad. Wiss., 1903, 28: 199-318. 


\section{R. R. Sturrock}

12. I. Hardesty, 'On the development and nature of the neuroglia', Am. J. Anat., 1904, 3: 229-268.

13. A. Peters, S. L. Palay and H. de F. Webster, The fine structure of the nervous system, New York, Hoeber (Harper \& Row), 1970, p. 105.

14. W. B. Lewis, 'On the comparative structure of the cortex cerebri', Brain, 1879, 1: 79-96; and W. B. Lewis, 'The structure of the first or outermost layer of the cerebral cortex', Edinb. med. J., 1897, 1: 573-592.

15. W. F. Robertson, 'On a new method of obtaining a black reaction in certain tissueelements of the central nervous system (platinum method)', Scott. med. surg. J., 1899, 4: 23-30.

16. Ibid., pp. 28 and 29.

17. W. F. Robertson, A textbook of pathology in mental diseases, Edinburgh, Clay, 1900.

18. W. F. Robertson, 'New methods of imbedding fresh and hardened tissue', J. Anat. Physiol., Lond., 1890, 24: 230-235.

19. J. Middlemass and W. F. Robertson, 'Pathology of the nervous system in relation to mental diseases Article I', Edinb. med. J., 1894, 40: 509-518; Article II, ibid., 1895, 40: 623-632; Article III, ibid., 704-729; Article IV, ibid., 813-824; Article V, ibid., 902-910; Article VI, ibid., 997-1006; W. F. Robertson, 'Pathology of the nervous system in relation to mental diseases', ibid., 1896, 41: 613-633, 814-824.

20. Robertson, op. cit., note 17 above.

21. W. F. Robertson, 'Note on Weigert's theory regarding the structure of the neuroglia', J. ment. Sci., 1897, 43: 67-72.

22. W. F. Robertson, 'The normal histology and pathology of the neuroglia (in relation specially to mental diseases)' ibid., 733-752.

23. Ibid., p. 743.

24. B. Messier, C. P. Leblond and I. Smart, 'Presence of D.N.A. synthesis and mitosis in the brain of young adult mice', Expl. Cell Res., 1958, 14: 224-226.

25. I. Smart and C. P. Leblond, 'Evidence for division and transformation of neuroglial cells in the mouse brain, as derived from radioautography after injection of thymidine$H^{32}$, J. comp. Neurol., 1961, 116: 349-367. (Iain Smart is, coincidentally, like W. F. Robertson, Watsonian and graduate of Edinburgh University.)

26. E. A. Ling, J. A. Paterson, A. Privat, S. Mori and C. P. Leblond, 'Investigation of glial cells in semithin sections. I. Identification of glial cells in the brain of young rats', J. comp. Neurol., 1973, 149: 43-72; E. A. Ling and C. P. Leblond, 'Investigation of glial cells in semithin section. II. Variation with age in the number of the various glial cell types in rat cortex and corpus callosum', ibid., 73-82; J. A. Paterson, A. Privat, E. A. Ling and C. P. Leblond, 'Investigation of glial cells in semithin sections. III. Transformation of subependymal cells, as shown by radioautography after ' $\mathrm{H}$ Thymidine injection into the lateral ventricle of the brain of young rats', ibid., 83-102.

27. W. F. Robertson, 'The normal histology and pathology of the neuroglia (in relation to mental diseases)', Edinb. Hosp. Rep., 1898, 5: 240-271.

28. Robertson, op. cit., note 16 above.

29. W. F. Robertson, 'A microscopic demonstration of the normal and pathological histology of mesoglia cells', J. ment. Sci., 1900, 46: 724; and op. cit., note 16 above.

30. W. Penfield, 'Oligodendroglia and its relation to classical neuroglia', Brain, 1924, 47: 430-452.

31. Robertson, op. cit., note 17 above, p. 187.

32. S. Mori and C. P. Leblond, 'Identification of microglia in light and electron microscopy', J. comp. Neurol., 1969, 135: 57-80.

33. M. Baron and A. Gallego, 'The relation of the microglia with the pericytes in the rat cerebral cortex', Z. Zellforsch. mikrosk. Anat., 1972, 128: 42-57.

34. M. A. Matthews, "Microglia and reactive " $M$ " cells of degenerating central nervous system: does similar morphology and function imply a common origin?', Cell and Tissue Research, 1974, 148: 477-491. 


\section{William Ford Robertson (1867-1923)}

35. R. R. Sturrock, 'Histogenesis of the anterior limb of the anterior commissure of the mouse brain. III. An electron microscopic study of gliogenesis', J. Anat., 1974, 117: 37-53.

36. P. del Rio Hortega, 'Histogénesis y evolución normal; exodo y distribucion regional de la microglia', Mem. R. Soc. esp. Hist. Nat., 1921, 11 : 213-268.

37. J. E. Vaughn and A. Peters, 'A third neuroglial cell type', J. comp. Neurol., 1968, 133: 269-288.

38. J. E. Vaughn and R. P. Skoff, 'Neuroglia in experimentally altered central nervous system' in, G. H. Bourne (editor), The structure and function of nervous tissue, New York and London, Academic Press, 1972, vol. 5, pp. 39-72.

39. E. A. Ling, 'The subependyma of the primate, slow loris (Nycticebus coucang coucang)', Tissue and cell, 1974, 6:361-370.

40. J. Langman, Medical embryology, 2nd ed., Edinburgh and London, E. \& S. Livingstone, 1969.

41. U. Cerletti, 'Studi recente sull' istogenesi della neuroglia', Riv. sper. Freniat. Med. leg. Alien. ment., 1908, 33: Fasc. 4.

42. P. del Rio Hortega, 'El "tercer elemento" de los centros nervosus', Boln. Soc. esp. Biol., 1919, 9: 69-120.

43. W. F. Robertson, Walks from Wooler, Newcastle upon Tyne, Reid, 1926.

44. Robertson, op. cit., note 15 above.

45. Penfield, op. cit., note 30 above, p. 433. 